\title{
Effect of infused vasoactive intestinal peptide on airway function in normal subjects
}

\author{
JAMES B D PALMER, FRANCIS M C CUSS, JOHN B WARREN, MARION BLANK, \\ STEPHEN R BLOOM, PETER J BARNES
}

\begin{abstract}
From the Department of Medicine (Respiratory and Endocrinology Divisions), Royal Postgraduate Medical School, Hammersmith Hospital, London
\end{abstract}

ABSTRACT Vasoactive intestinal peptide, one of the putative neurotransmitters of non-adrenergic inhibitory nerves in human airways, is a potent relaxant of human airways in vitro. Previous in vivo studies of infused vasoactive intestinal peptide in asthmatic subjects have shown only a small bronchodilator effect, which may have been secondary to the cardiovascular effects of the peptide. The effect on airway function of infused vasoactive intestinal peptide was studied in normal subjects, who readily develop bronchodilatation in response to a $\beta$ agonist. Separate experiments were designed to assess whether there is any synergy between this peptide and the $\beta$ agonist isoprenaline. Incremental doses of 1,3 , and $6 \mathrm{pmol} / \mathrm{kg} / \mathrm{min}$ of vasoactive intestinal peptide were infused for 15 minutes. At $6 \mathrm{pmol} / \mathrm{kg} / \mathrm{min}$ it caused a mean fall in systolic blood pressure from 108 to $88 \mathrm{~mm} \mathrm{Hg}$ and a rise in heart rate from 71 to 95 beats/min. There was no significant change in specific airways conductance (sGaw) at any dose of vasoactive intestinal peptide. No significant changes were found with placebo. Isoprenaline $(400 \mu \mathrm{g})$ given by inhalation at the end of the infusion produced a mean increase in sGaw of $50 \%$. Infused peptide caused no significant change in the cumulative doseresponse curve for inhaled isoprenaline. The lack of effect of vasoactive intestinal peptide on airway responses in vivo may be due to rapid enzymatic breakdown of the peptide or to the fact that dosage has to be limited by the cardiovascular effects.

Non-adrenergic inhibitory nerves have been described in the airways of several species, including man. ${ }^{1}$ As histological and functional studies have shown no evidence for direct sympathetic innervation of human airway smooth muscle, ${ }^{2-6}$ non-adrenergic nerves are the only known inhibitory neural mechanism and may therefore be particularly important in man. Although the neurotransmitter in this sytem is not yet known, the most likely candidate is vasoactive intestinal peptide, a 28 amino acid polypeptide that is localised to nerves in human airways. ${ }^{7-10}$ Although in vitro it is a potent relaxant of human bronchial smooth muscle, ${ }^{11}$ in vivo studies of the peptide have shown equivocal results. Inhaled vasoactive intestinal peptide has no effect on resting airway calibre in asthmatic subjects, who readily develop bronchodilatation in response to an inhaled $\beta$ agonist, and it shows only minor protection against histamine

Address for reprint requests: Professor Peter Barnes, Department of Clinical Pharmacology, Cardiothoracic Institute, Brompton Hospital, London SW3 6HP. induced bronchoconstriction. ${ }^{12}$ One study of infused vasoactive intestinal peptide in asthmatic subjects has shown a small bronchodilator effect, ${ }^{13}$ which may have been secondary to the cardiovascular effects of the infused peptide. ${ }^{14}$

We have now studied the effects of infused vasoactive intestinal peptide in normal subjects, who all developed bronchodilatation in response to an inhaled $\beta$ agonist in preliminary studies. There is in vitro evidence in some tissues that vasoactive intestinal peptide and sympathomimetics may be synergistic. ${ }^{15}$ We have assessed this in separate experiments by studying the effect of the infused peptide on the dose-response curve obtained for inhaled isoprenaline from the same subjects.

\section{Methods}

SUBJECTS

We studied six non-asthmatic, non-smoking male volunteers (two of whom were atopic), with a mean age of 31 years (range 27-37). All had shown a rise in specific airways conductance (sGaw) of at least $30 \%$ 
after inhaled isoprenaline $(400 \mu \mathrm{g})$ in a pilot study. Subjects attended the laboratory on two separate occasions, at the same time of day, and did not take any beverages containing xanthines for at least 12 hours before the study. The protocol was approved by the hospital ethics committee and all subjects gave informed consent.

\section{EXPERIMENTAL PROTOCOL}

Changes in airway calibre were recorded by measurement of sGaw in a computerised, constant volume body plethysmograph. ${ }^{16}$ Subjects panted at a frequency of about $2 \mathrm{~Hz}$. Before the start of the infusion subjects rested for 15 minutes, during which time a venous cannula (Butterfly 19G, Abbot Laboratories) was inserted into both forearms, one for sampling for determination of vasoactive intestinal peptide concentration in plasma and one for infusion of the peptide. At the end of this period baseline measurements of sGaw (mean of six measurements), radial pulse rate, blood pressure, and plasma vasoactive intestinal peptide were made. Subjects then received either synthetic vasoactive intestinal peptide (Bachem, Torrance, California), or vehicle (Haemaccel, Hoechst, Middlesex) in a double blind randomised fashion. Incremental doses of 1,3 , and $6 \mathrm{pmol} / \mathrm{kg} / \mathrm{min}$ were infused for 15 minutes each. At the end of each infusion period sGaw, heart rate, blood pressure, and plasma vasoactive intestinal peptide were measured. The infusion was continued in the body plethysmograph while measurements of sGaw were made. Values for blood pressure and heart rate are expressed as the mean of three measurements, heart rate having been measured for one minute on each occasion. On completion of the infusion isoprenaline $400 \mu \mathrm{g}$ was given by metered dose inhaler and sGaw was measured after five minutes.

In a separate experiment four subjects received either vehicle or vasoactive intestinal peptide $6 \mathrm{pmol} / \mathrm{kg} / \mathrm{min}$ for 10 minutes before and then during an isoprenaline dose-response study, in which cumulative doses of $10,35,60,110$, and $410 \mu \mathrm{g}$ were given by metered dose aerosol. sGaw was measured five minutes after each dose of isoprenaline.

\section{VASOACTIVE INTESTINAL PEPTIDE ASSAY}

Plasma vasoactive intestinal peptide was collected in lithium heparin tubes containing $200 \mu$ l of aprotinin (Bayer) to prevent enzymatic breakdown of vasoactive intestinal peptide. Samples were placed immediately in ice and spun within five minutes, the plasma being stored at $-20^{\circ} \mathrm{C}$ for subsequent analysis. The assay of plasma vasoactive intestinal peptide concentrations was performed by radioimmunoassay. ${ }^{17}$ Natural porcine vasoactive intestinal peptide was used as a standard. The assay was able to detect $0.4 \mathrm{fmol}$ of the peptide in an assay tube with $95 \%$ confidence; the intra-assay and interassay variations were $7 \%$ and $18 \%$.

\section{DATA ANALYSIS}

Data are expressed as absolute values for blood pressure and heart rate before and after vasoactive intestinal peptide infusion or vehicle and as percentage change in sGaw from baseline values. sGaw before and after the infusions and change in the sGaw during the isoprenaline dose-response studies were analysed by Wilcoxons rank sum test. Blood pressure and pulse before and after the infusions were analysed by two way analysis of variance and Students $t$ test, a level of $p<0.05$ being taken as significant. All values are given as means with standard errors in parentheses.

\section{Results}

There was no significant difference between baseline mean sGaw measurements on the placebo and vasoactive intestinal peptide study days, the values being 1.79 (SE 0.16) and $1.90(0.28) \mathrm{s}^{-1} \mathrm{kPa}^{-1}$; and neither infused peptide nor vehicle caused a significant change in sGaw from baseline values. Absolute values of $\mathrm{sGaw}\left(\mathrm{s}^{-1} \mathrm{kPa}^{-1}\right)$ during the peptide infusion were $2.03(\mathrm{SE} 0.21)$ at $1 \mathrm{pmol} / \mathrm{kg} / \mathrm{min}, 1.91(0.31)$ at $3 \mathrm{pmol} / \mathrm{kg} / \mathrm{min}$, and $2.01(0.22)$ at $6 \mathrm{pmol} / \mathrm{kg} / \mathrm{min}$. At the end of the infusion of vasoactive intestinal peptide and vehicle isoprenaline produced percentage

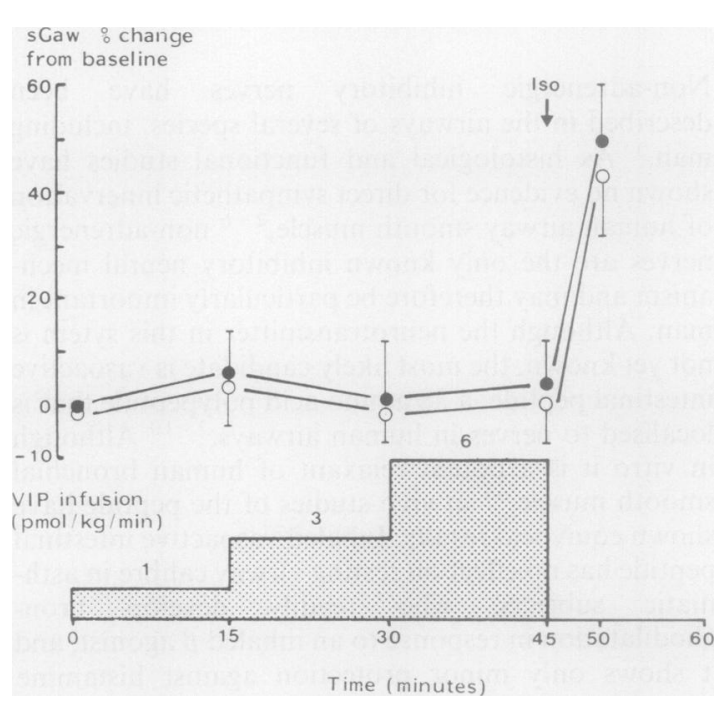

Fig 1 Effects of infused vasoactive intestinal peptide (○) and vehicle $(\bigcirc)$ on specific airways conductance (sGaw), expressed as percentage change from baseline values. Isoprenaline $400 \mu \mathrm{g}$ (Iso) was given by inhalation at the end of the infustion. 


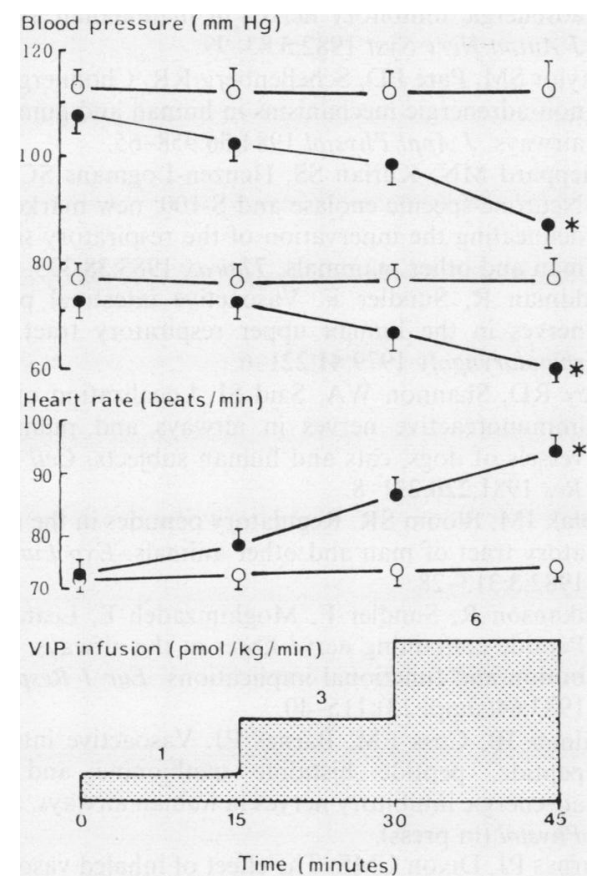

Fig 2 Effects of infused vasoactive intestinal peptide $(V I P-O)$ and vehicle $(O)$ on systolic and diastolic blood pressure and heart rate. ${ }^{*} p<0.01$ for significant difference between pretreatment and post-treatment values.

increases in sGaw of 50 (9) and 46 (11) respectively from baseline values (fig l). At $6 \mathrm{pmol} / \mathrm{kg} / \mathrm{min}$ the peptide caused a mean fall in systolic pressure from $108(4)$ to $88(5) \mathrm{mm} \mathrm{Hg}$ and in diastolic pressure from 73 (3) to 60 (3) $\mathrm{mm} \mathrm{Hg}$ and a rise in heart rate from 71 (4) to 95 (4) beats $/ \mathrm{min}$ ( $\mathrm{p}<0.01$ in each case). At $3 \mathrm{pmol} / \mathrm{kg} / \mathrm{min}$ a significant fall in diastolic blood pressure and rise in heart rate were also observed (fig 2). No significant changes in heart rate or blood pressure were seen with placebo infusion. Plasma vasoactive intestinal peptide concentrations determined at the end of each infusion period were $3.6(0.5) \mathrm{pmol} / \mathrm{l}$ at $1 \mathrm{pmol} / \mathrm{kg} / \mathrm{min}, 14(0.5) \mathrm{pmol} / \mathrm{l}$ at $3 \mathrm{pmol} / \mathrm{kg} / \mathrm{min}$, and $34.6(1.8) \mathrm{pmol} / \mathrm{l}$ at $6 \mathrm{pmol} /$ $\mathrm{kg} / \mathrm{min}$.

There was no significant difference in the cumulative dose-response curve obtained for isoprenaline (expressed as percentage change in sGaw from baseline values) during infusion with either vasoactive intestinal peptide or vehicle (fig 3).

\section{Discussion}

These results show that infused vasoactive intestinal peptide, in doses that have appreciable cardiovascular effects, has no bronchodilator effect in normal sub- jects. This finding is at variance with the results of a previous study, which showed a small bronchodilator effect in asthmatic subjects, ${ }^{13}$ though it is possible that the changes in airway calibre in that study were secondary to the cardiovascular effects of the infused peptide and not a primary effect of the peptide at airway receptor sites. ${ }^{14}$ The cardiovascular effects of vasoactive intestinal peptide in the present study, however, did not result in bronchodilatation, so possibly asthmatic subjects respond differently. In our study cardiovascular responses, which include appreciable facial flushing, hypotension, and tachycardia, were the dose limiting effects of the peptide; they occur when plasma concentrations are in the picomolar range. In vitro the $\mathrm{EC}_{50}$ of vasoactive intestinal peptide in human bronchi (that is, the concentration of the peptide required to reverse $50 \%$ of induced contraction) is about $0.01 \mu \mathrm{mol} / 1 .{ }^{11}$ This concentration would not be achieved in vivo by infusion because of dose limiting cardiovascular side effects. In vitro studies in man suggest that vasoactive intestinal peptide may be more potent in relaxing vascular than airway smooth muscle. ${ }^{18}$ Normal subjects were chosen as it has been suggested that asthmatic subjects might have a less effective non-adrenergic nervous system or may be less responsive to the putative neurotransmitter action of vasoactive intestinal peptide. ${ }^{1}$ The lack of effect of the infused peptide on airway tone may be explained by its failure to diffuse from the circulation to reach airway receptor sites in sufficient concentration, or by its rapid enzymatic breakdown in the systemic circulation and the limitation in the dose that can be given because of cardiovascular effects. The inhaled peptide similarly has no

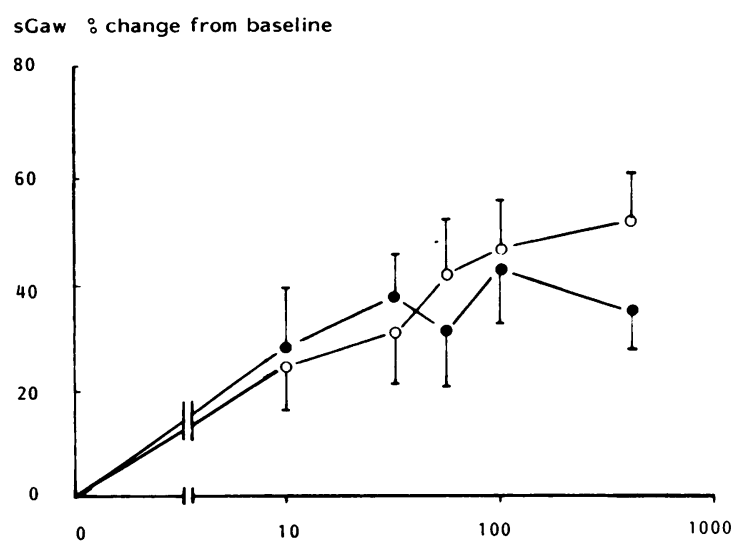

Cumulative inhaled dose of isoprenaline $(\mu \mathrm{g})$

Fig 3 Effect of infused vasoactive intestinal peptide (O) and vehicle $(\bigcirc)$ on cumulative dose-response curves for inhaled isoprenaline (specific airways conductance (sGaw) expressed as the percentage change from baseline values). 
effect on resting airway tone and only a small protective effect against histamine induced bronchoconstriction. ${ }^{12}$

Despite the disappointing in vivo results there is accumulating in vitro evidence that vasoactive intestinal peptide may the neurotransmitter in nonadrenergic inhibitory nerves in human airways. It is localised, according to immunohistochemical studies, to human airway nerves ${ }^{7-10}$; it appreciably relaxes human bronchial smooth muscle in vitro, being about 50 times more potent than isoprenaline; and it mimics the non-adrenergic neural relaxation induced by electrical field stimulation. ${ }^{11}$ In other species electrical field stimulation of isolated airway smooth muscle causes a rise in the concentration of vasoactive intestinal peptide in the bathing medium, which can be blocked with the nerve blocker tetrodotoxin, implying neural release. ${ }^{1920}$ Another possible candidate as neurotransmitter is the peptide histidine methionine, which is structurally similar to vasoactive intestinal peptide, and coded by the same genome. ${ }^{21}$ Recent immunohistochemical studies have shown that the two peptides coexist in airway nerves of several species, including man, ${ }^{22}$ and in vitro studies on human bronchi show it to be approximately equipotent to vasoactive intestinal peptide. ${ }^{11}$ Neither of these peptides, however, can be confirmed as the neurotransmitter of non-adrenergic inhibitory nerves until specific blockers are identified.

Studies in other tissues have suggested that vasoactive intestinal peptide and sympathomimetics are synergistic. ${ }^{15}$ Although both stimulate adenylate cyclase to produce their effects, possibly different pools of cyclic AMP are mobilised. Vasoactive intestinal peptide might therefore potentiate the effect of $\beta$ agonists on the airways despite having no effect on bronchomotor tone. Our studies, however, have shown that the peptide has no significant effect on the bronchodilator dose-response curves for isoprenaline.

We conclude that infused vasoactive intestinal peptide has no demonstrable effect on airway tone in normal subjects and because of its dose limiting cardiovascular effects is unlikely to have any therapeutic potential in asthmatic subjects.

JP and FMC are supported by the Medical Research Council.

\section{References}

1 Barnes PJ. The third nervous system in the lung: physiology and clinical perspectives. Thorax 1984; 39:561-7.

2 Richardson J, Béland J. Non-adrenergic inhibitory nerves in human airways. $J$ Appl Physiol 1976;41:764-71.

3 Davis C, Kannan MS, Jones TR, Daniel EE. Control of human airway smooth muscle: in vitro studies. $J$ Appl Physiol 1982;53:1080-7.

4 Doidge JM, Satchell DG. Adrenergic and non- adrenergic inhibitory nerves in mammalian airways. J Auton Nerv Syst 1982;5:83-99.

5 Taylor SM, Paré PD, Schellenberg RR. Cholinergic and non-adrenergic mechanisms in human and guinea-pig airways. J Appl Physiol 1984;56:958-65.

6 Sheppard MN, Kurian SS, Henzen-Logmans SC, et al. 을 Neurone-specific enolase and S-100: new markers for delineating the innervation of the respiratory tract in $\overrightarrow{-}$ man and other mammals. Thorax 1983;38:333-40.

7 Uddman R, Sundler F. Vasoactive intestinal peptide $\overrightarrow{\vec{\omega}}$ nerves in the human upper respiratory tract. Otorhinolaryngoly 1979;41:221-6.

8 Dey RD, Shannon WA, Said SI. Localization of VIPimmunoreactive nerves in airways and pulmonary $\stackrel{\vec{A}}{\rightarrow}$ vessels of dogs, cats and human subjects. Cell Tissue Res 1981;220:231-8.

9 Polak JM, Bloom SR. Regulatory peptides in the respiratory tract of man and other animals. Exp Lung Res 음 1982;3:313-28.

10 Hakanson R, Sundler F, Moghimzadeh E, Leander S. ( ) Peptide-containing nerve fibres in the airways: distri- $\mathbb{D}$ bution and functional implications. Eur $J$ Respir Dis 1983;64(suppl 13):115-40.

11 Palmer JB, Cuss FM, Barnes PJ. Vasoactive intestinal peptide, peptide histidine methionine and non- $\vec{\oplus}$ adrenergic inhibitory nerves in human airways. $J$ Appl Physiol (in press).

12 Barnes PJ, Dixon CMS. The effect of inhaled vasoactive intestinal peptide on bronchial reactivity to histamine in humans. Am Rev Respir Dis 1984;130:162-66.

13 Morice A, Unwin RJ, Sever PS. Vasoactive intestinal peptide causes bronchodilation and protects against histamine induced bronchoconstriction in asthmatic subjects. Lancet 1983;ii:1255-6.

14 Barnes PJ, Bloom SR, Dixon CMS. VIP and asthma. Lancet $1984 ; \mathrm{i}: 112$.

15 Magistretti PJ, Schorderet M. VIP and noradrenaline act synergistically to increase cyclic AMP in cerebral cortex. Nature 1984;308:280-2.

16 Chowienczyk PJ, Rees PJ, Payne P, Clark TJH. A new method for computer-assisted determination of airways resistance. J Appl Physiol 1981;50:672-8.

17 Mitchell SJ, Bloom SR. Measurement of fasting and postprandial plasma VIP in man. Gut 1978;19:1043-8.

18 Greenberg B, Rhoden K, Barnes PJ. Characteristics of VIP and PHI relaxation of bovine and human pul- $O$ monary artery [abstract]. Thorax 1985;40:715.

19 Cameron AC, Johnson CF, Kirkpatrick CT, Kirkpatrick MCA. The quest for the inhibitory neurotransmitter in bovine tracheal smooth muscle. $Q J$ Exp o

Physiol 1983;68:413-26.
20 Matsuzaki Y, Hamasaki Y, Said SI. Vasoactive intes- $\mathrm{N}$ tinal polypeptide: a possible neurotransmitter of non- $\omega$ adrenergic relaxation of guinea-pig airways. Science $\underset{<}{\sigma}$ 1980;210:1252-3.

21 Itoh N, Obata K, Yanaihara N, Okamoto H. Human preprovasoactive intestinal polypeptide contains a novel PHI-27-like peptide PHM-27. Nature 1983;304: 547-9.

22 Lundberg JM, Fahrenkrug J, Hokfelt T, etal. Coexistence of peptide $\mathrm{HI}$ (PHI) and VIP in nerves regu- $\frac{\Omega}{\Phi}$ lating blood flow and bronchial smooth muscle tone in various animals including man. Peptides 1984;5: ซ 593-606. 